\title{
Is Vegetable Variety Evaluation and Reporting Becoming A Lost Art? An Industry Perspective
}

Tom V. Williams ${ }^{1}$ and Warren Roberts ${ }^{2}$

AdDitional INDEX wORDs. watermelon, Citrullus lanatus, variety performance, standardization, reporting

Summary. Is there a more important component to a grower's production practices than the choice of the best variety to plant? Probably not, yet there is less public vegetable variety testing than ever before, despite the increasing introduction of new varieties by the seed industry. This article examines the reasons for fewer vegetable variety trials, discusses the benefits of good variety reporting, and considers the keys to conducting a successful vegetable variety trial. Vegetable variety performance could be interpreted best on a regional basis if a standard format for evaluating each species is developed. One such attempt at standardizing watermelon (Citrullus lanatus) evaluation is presented. Finally, several recent vegetable trial reports are discussed to point out the difference of each and what additional data could have been provided.

I am happy that I was offered an opportunity to address this topic. In the more than 30 years that I have been involved with vegetable variety development, there has been an obvious erosion of variety trial reporting in terms of quantity and, to some extent, quality. I do not mean to say that the evaluators of today need to mimic Joe Steinke of Rutgers University who actually had a huge rubber ink pad and used to ink blot the head of a cabbage (Brassica oleracea Capitata Group) variety in his cabbage variety reports and draw the bush and pod setting habit of each variety for his bean (Phaseolus vulgaris) reports. But, speaking for the seed industry, I hope to be able to bring to your attention the importance of goodquality variety performance reporting in this paper. After all, when looking at the inputs that growers use in their production practices, the choice of the appropriate variety to plant has to be one of the most critical.

Trade names are for information only and do not imply endorsement by the authors.

${ }^{1}$ Watermelon breeder, Syngenta Seeds, 10290 Greenway Road, Naples, FL 34114-3199; Tom.Williams@syngenta.com.

${ }^{2}$ Associate professor, Oklahoma State University, Dept. of Horticulture and Landscape Architecture, P.O. Box 128, Lane, OK 74555; wroberts@lane-ag.org. 

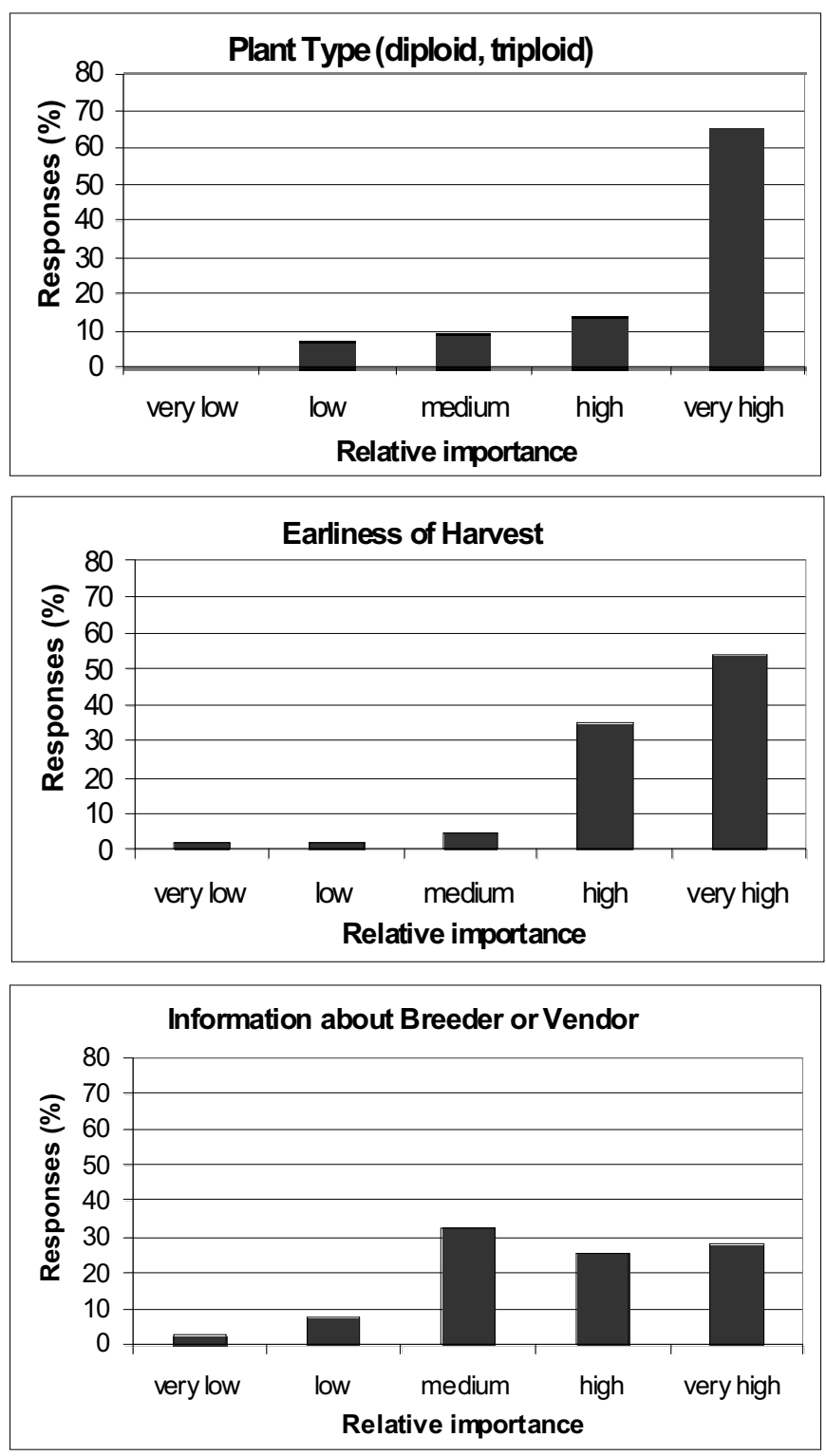

Fig. 1. Relative importance of factors (plant type, earliness of harvest, and information about breeder or vendor) when conducting watermelon variety evaluations. Each bar represents the percentage of survey respondents who categorized each factor at a given level.

\section{The truth hurts!}

Some of the main reasons for fewer variety trial reports include the following.

Fewer eVAluators. There are fewer extension personnel and fewer public vegetable breeders to conduct vegetable variety trials. Arlie Powell of Auburn University (personal communication) indicated that there are 200 fewer extension personnel in Alabama than in previous years. Today, almost all new vegetable varieties come from the private sector and, despite a myriad of seed company mergers, it seems that there are more varieties being commercialized than ever before. This is due to the competitive nature of the industry, coupled with the shorter life cycle of new commercial varieties. For the grower to sort out the best new candidates for planting, it is critical to have current information regarding variety performance.
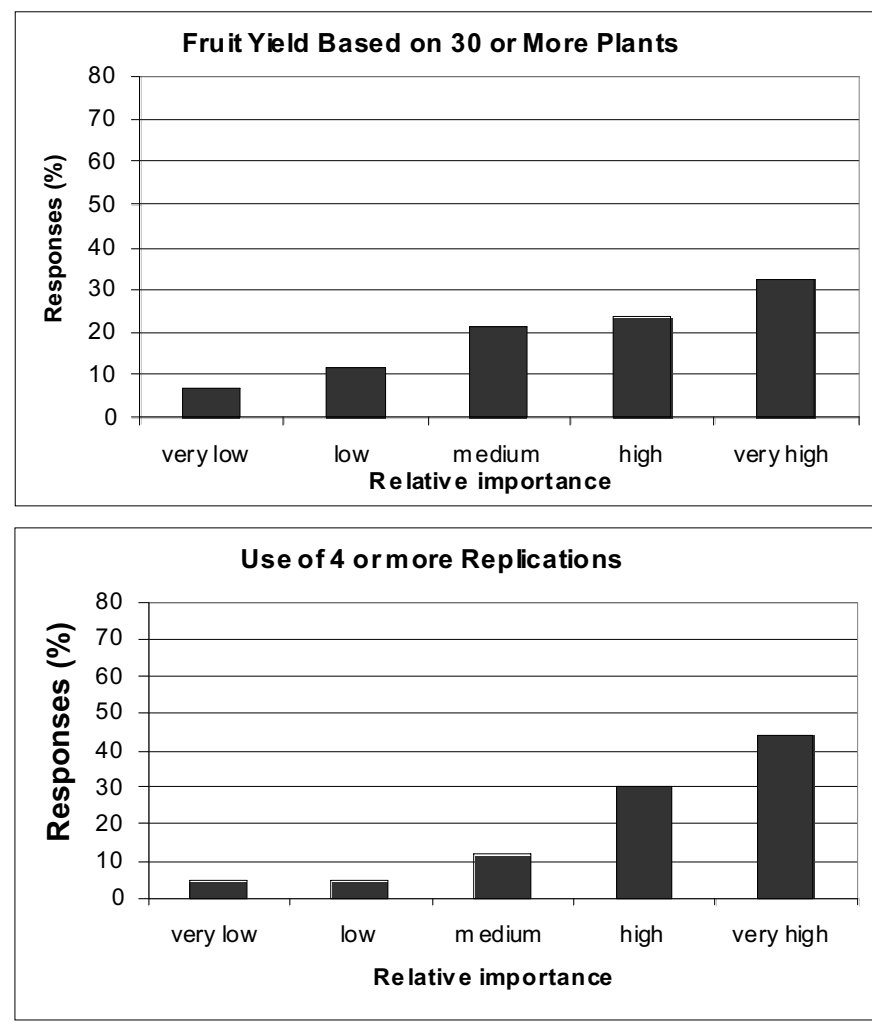

Fig. 2. Relative importance of factors (experimental plots having 30 or more plants, with four or more replications), when conducting watermelon variety evaluations. Each bar represents the percentage of survey respondents who categorized each factor at a given level.
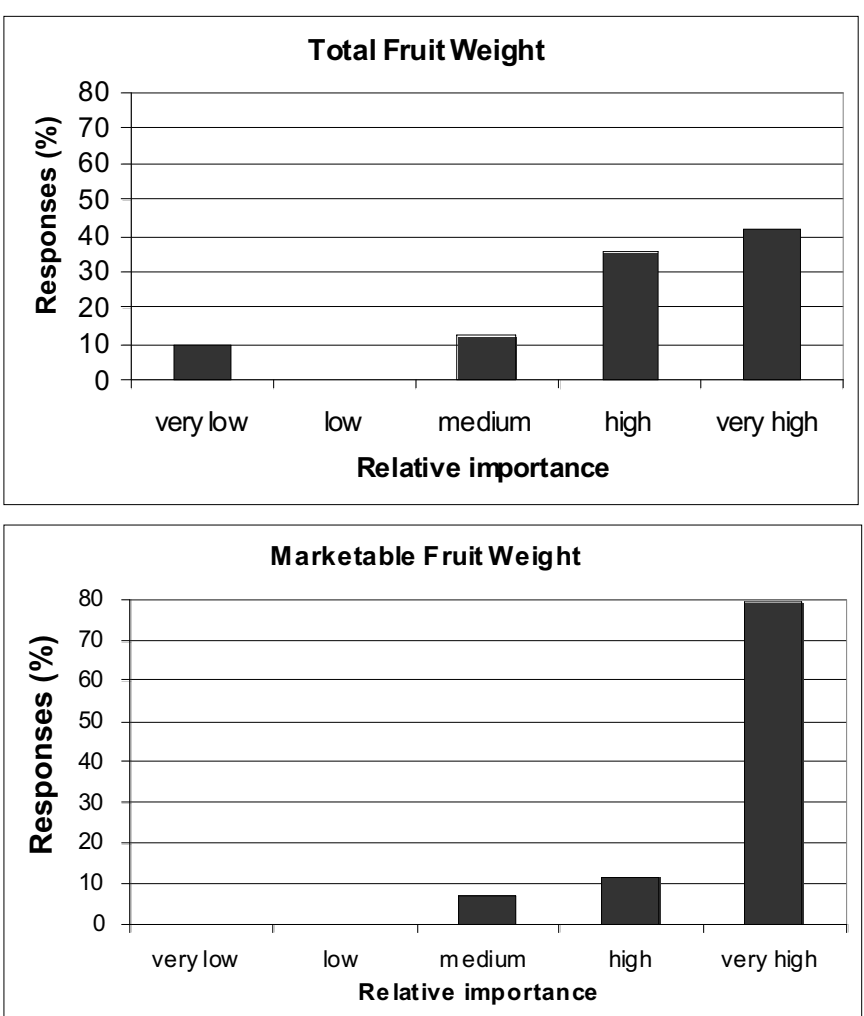

Fig. 3. Relative importance of factors (total fruit weight and marketable fruit weight) when conducting watermelon variety evaluations. Each bar represents the percentage of survey respondents who categorized each factor at a given level. 

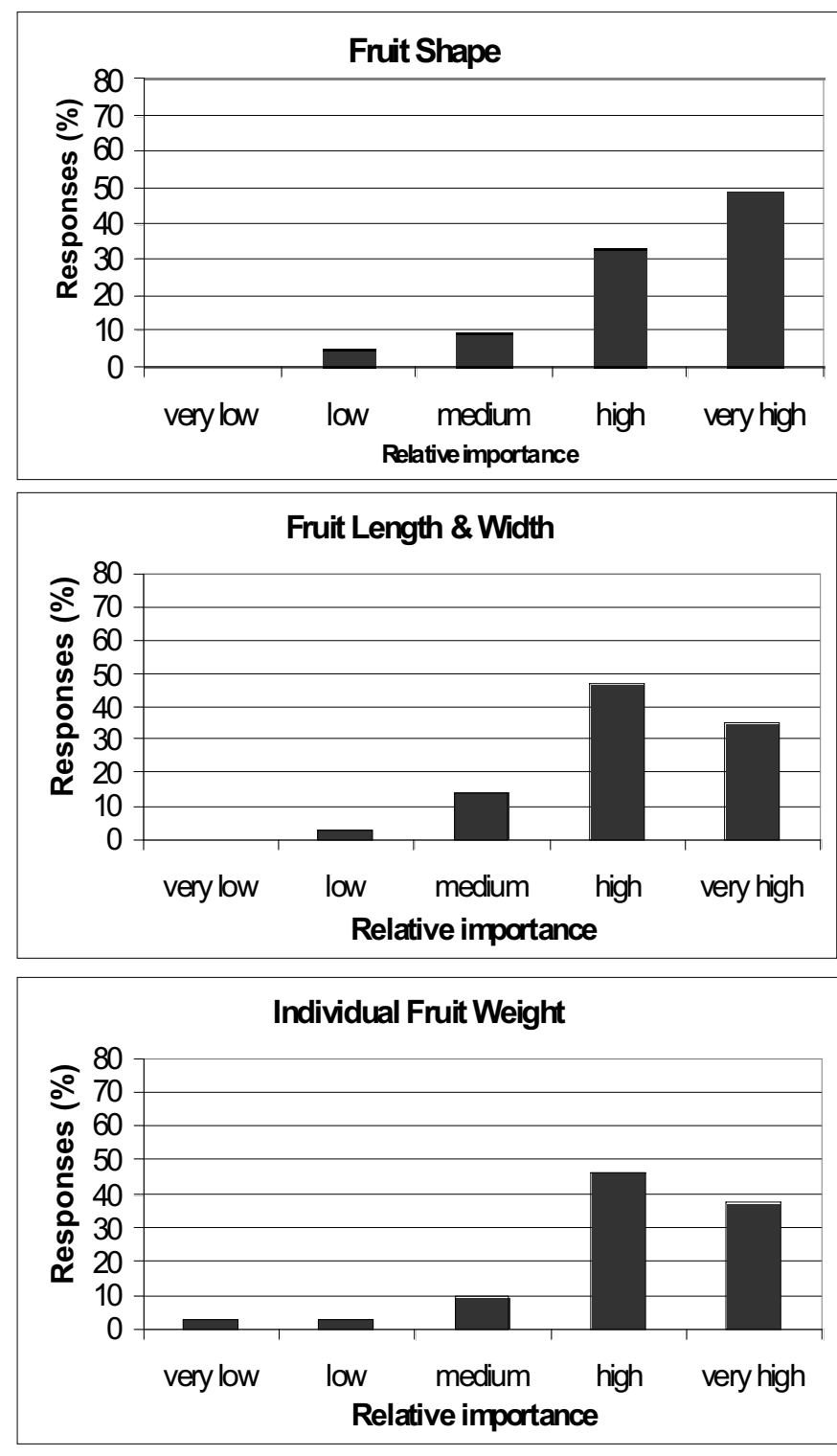
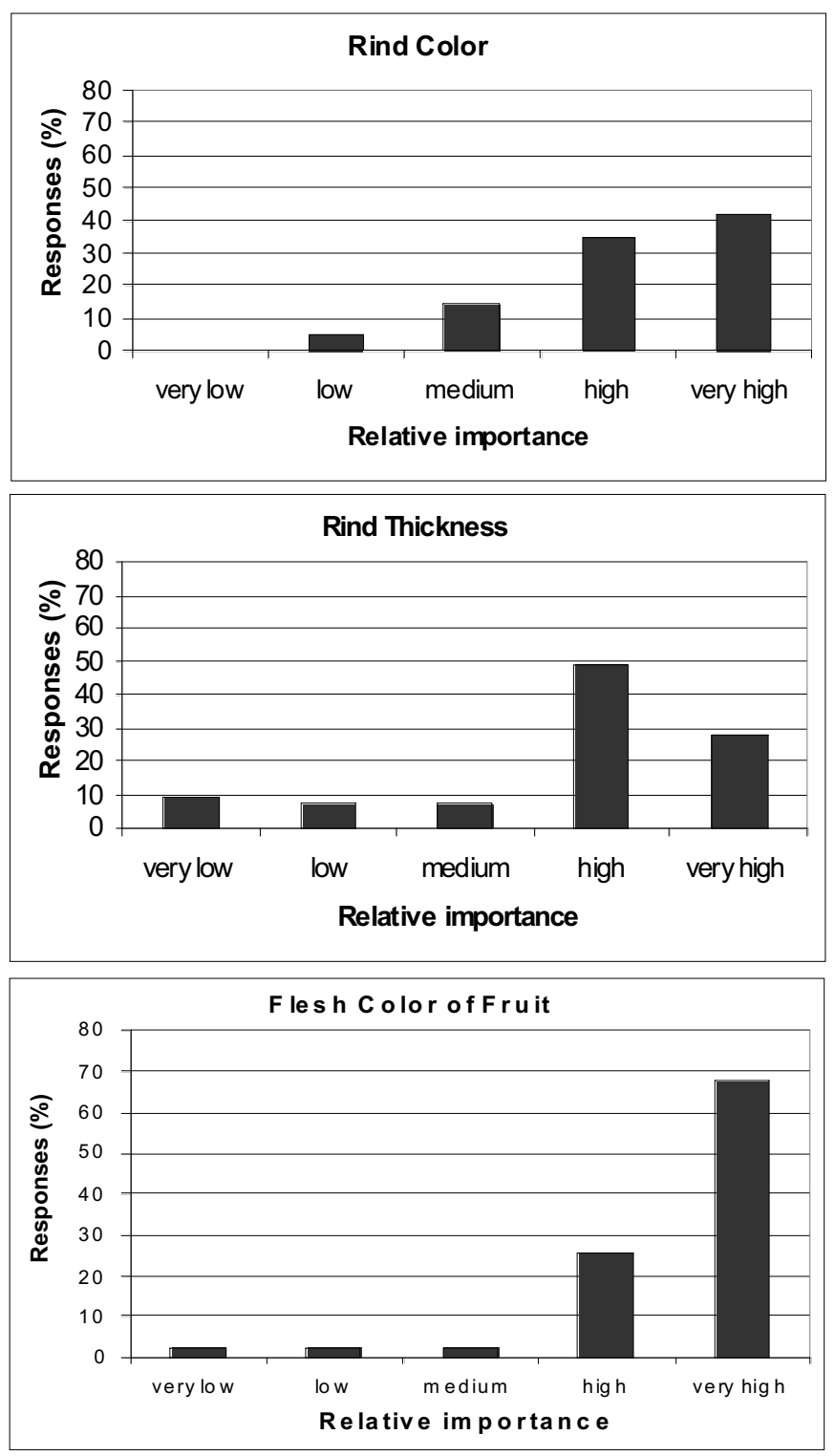

Fig. 4. Relative importance of factors (fruit shape, fruit length and width, individual fruit weight, rind color, rind thickness, and flesh color of fruit) when conducting watermelon variety evaluations. Each bar represents the percentage of survey respondents who categorized each factor at a given level.

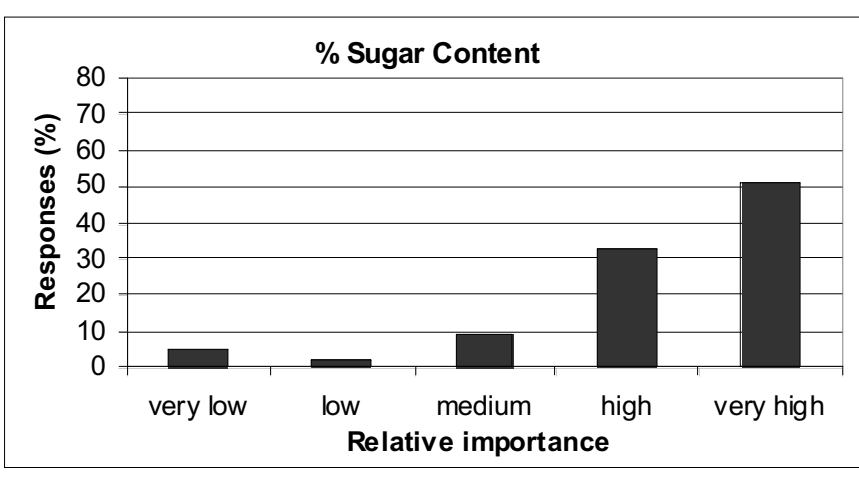

Fig. 5. Relative importance of fruit sugar content when conducting watermelon variety evaluations. Each bar represents the percentage of survey respondents who categorized each factor at a given level.
- "I appreciate your efforts in this area. $I$ think it is very important that we have some standards in watermelon variety evaluation."

- "The idea of trying to standardize trial condition and data collection form is excellent. In fact we are currently planning a workshop on vegetable variety evaluation."

- "Watermelon cultivar information available to growers is often incomplete and is mostly limited to yield, earliness, tolerance, and flesh color. More extensive cultivar characteristics are needed to address information needs of watermelon producers as well as brokers, shippers and nutritionists.”

Fig. 6. Selected comments from the watermelon survey respondents. 
Table 1. An example of a watermelon variety trial in which the fruit weight was less than normal due to high plant population.

\begin{tabular}{|c|c|c|c|c|c|c|c|}
\hline Variety & $\begin{array}{c}\begin{array}{c}\text { Yield } \\
(\mathbf{l b} / \text { acre })^{z}\end{array} \\
\end{array}$ & $\begin{array}{c}\text { Yield } \\
{\text { (fruit/acre) })^{y}}^{\left(\text {frut }^{2}\right.}\end{array}$ & $\begin{array}{l}\text { Early harvest } \\
\left(^{\%} \text { of total }\right)^{x, w}\end{array}$ & $\begin{array}{c}\text { Fruit wt } \\
\text { (lb/fruit) }^{\mathrm{v}}\end{array}$ & $\begin{array}{l}\text { Soluble solids } \\
\text { content }(\%)^{w}\end{array}$ & $\begin{array}{c}\text { Rind } \\
\text { necrosis }^{\mathrm{w}, \mathrm{u}}\end{array}$ & $\begin{array}{l}\text { Hollow } \\
\text { heart }^{\text {w,u }}\end{array}$ \\
\hline Scarlet Trio & 86,400 & 5870 & 32 & 14.7 & 11.4 & 1.2 & 1.8 \\
\hline Triple Prize & 80,800 & 6000 & 30 & 13.5 & 11.7 & 1.4 & 1.5 \\
\hline Crimson Sweet & 68,100 & 4310 & 50 & 15.8 & 12 & 1.1 & 1.1 \\
\hline HMX6910 & 52,900 & 4130 & 25 & 12.8 & 11.4 & 1.8 & 1.2 \\
\hline W3010 & 50,600 & 3870 & 29 & 13.1 & 12.4 & 1.3 & 1.2 \\
\hline
\end{tabular}

${ }^{\mathrm{z}} 1 \mathrm{lb} / \mathrm{acre}=1.1 \mathrm{~kg} \cdot \mathrm{ha}^{-1}$. Yield and size of melons based on melons greater than $10.0 \mathrm{lb}(4.54 \mathrm{~kg})$. Yield based on plant population of 2904 plants $/ \mathrm{acre}(7176$ plants $/$ ha $)$ or $15 \mathrm{ft}^{2}\left(1.4 \mathrm{~m}^{2}\right)$ per plant. Rows spaced $7.5 \mathrm{ft}(2.3 \mathrm{~m})$ apart with plants $2.0 \mathrm{ft}(0.6 \mathrm{~m})$ apart within rows.

yl fruit/acre $=0.4$ fruit $/$ ha.

xApproximately $35 \%$ of the total marketable yield was considered early. Simple means reported.

wAverage of at least three samples from each of four replications for the replicated trial or from each of three or four replications for the observational trial. Least squares means reported for replicated trial and simple means for observational trial.

${ }^{\mathrm{v}} 1.0 \mathrm{lb}=0.45 \mathrm{~kg}$.

"Rind necrosis and hollow heart incidence on a scale of 1 to 3 ( $1=$ none, $2=$ slight to moderate, $3=$ severe $)$.

Table 2. An example of seeded watermelon germination data. Such data are not a high priority since germination of diploids is generallyhigh.

\begin{tabular}{llcr}
\hline & Seed & \multicolumn{2}{c}{ Germination (\%) } \\
\cline { 3 - 4 } Variety & source $^{\mathbf{z}}$ & Avg & Stephenville, Texas \\
germination (\%)
\end{tabular}

${ }^{\mathrm{z} A b b o t t / C o b b}=$ Abbott and Cobb, Inc., Feasterville, Pa.; Seminis = Seminis Vegetable Seeds, Inc., Oxnard, Calif.; Willhite = Willhite Seed, Inc., Poolville, Texas.

Table 3. An example of a watermelon variety trial in which flesh color rating would have improved the data.

\begin{tabular}{|c|c|c|c|c|c|}
\hline \multirow[b]{2}{*}{ Variety } & \multirow{2}{*}{$\begin{array}{c}\text { Wt } \\
(\text { cwt/acre })^{\mathrm{z}}\end{array}$} & \multirow{2}{*}{$\begin{array}{c}\text { Avg } \\
\text { fruit wt } \\
(1 b)^{y}\end{array}$} & \multirow{2}{*}{$\begin{array}{c}\text { Soluble } \\
\text { solids } \\
(\%)\end{array}$} & \multicolumn{2}{|c|}{ Hollowheart } \\
\hline & & & & $(\%)$ & $(\text { inches })^{x}$ \\
\hline XWT 8706 & $117 \mathrm{ab}$ & $17.8 \mathrm{~b}-\mathrm{c}$ & $11.4 \mathrm{~b}$ & $25 \mathrm{a}-\mathrm{c}$ & $0.3 \mathrm{~b}$ \\
\hline DPSX 4572 & $168 \mathrm{ab}$ & $15.9 \mathrm{~b}-\mathrm{I}$ & $14.0 \mathrm{a}$ & $33 a-c$ & $0.6 \mathrm{~b}$ \\
\hline Hazera 103 & $113 \mathrm{ab}$ & $15.6 \mathrm{~b}-\mathrm{i}$ & $13.2 \mathrm{ab}$ & $67 a-c$ & $0.8 \mathrm{~b}$ \\
\hline
\end{tabular}

${ }^{\mathrm{z}} 1 \mathrm{cwt} /$ acre $=112.1 \mathrm{~kg} \cdot \mathrm{ha}^{-1}$.

${ }^{\mathrm{y}} 1.0 \mathrm{lb}=0.45 \mathrm{~kg}$.

${ }^{\mathrm{x}} 1.0$ inch $=2.54 \mathrm{~cm}$

w'Mean separation by Duncan's multiple range test, $P=0.05$.

Table 4. An example of a watermelon trial report in which the flesh color should have been rated for the degree of redness.

\begin{tabular}{|c|c|c|c|c|c|c|c|c|c|}
\hline Variety & $\begin{array}{c}\text { Seed } \\
\text { source }^{\mathrm{z}}\end{array}$ & $\begin{array}{c}\text { Yield } \\
{\text { (lb/acre })^{y}}^{\text {(lb/and }}\end{array}$ & $\begin{array}{c}\text { Sugar } \\
\text { content } \\
(\%) \\
\end{array}$ & $\begin{array}{c}\text { Fruit } \\
\text { length } \\
\text { (inches) }^{x}\end{array}$ & $\begin{array}{c}\text { Fruit } \\
\text { width } \\
\text { (inches) }\end{array}$ & $\begin{array}{l}\text { Rind } \\
\text { thickness } \\
\text { (inches) }\end{array}$ & $\begin{array}{c}\text { Fruit } \\
\text { wt } \\
(1 \mathbf{b})^{w}\end{array}$ & $\begin{array}{c}\text { Melon } \\
\text { type }^{v}\end{array}$ & $\begin{array}{l}\text { Flesh } \\
\text { color }\end{array}$ \\
\hline Stars n Stripes & Seminis & 48,627 & 9.9 & 17.4 & 8.2 & 1 & 15.6 & 1 & Red \\
\hline AU-Jubilant & Hollar & 43,549 & 9.4 & 16.9 & 8.4 & 0.9 & 19.4 & 1 & Red \\
\hline WX55 & Willhite & 30,242 & 10.7 & 10.3 & 9.2 & 0.9 & 12.6 & 1 & Red \\
\hline WX22 & Willhite & 47,956 & 10.4 & 14.1 & 9.4 & 0.7 & 17.9 & 2 & Red \\
\hline EX 4203337 & Seminis & 39,229 & 9.8 & 10.8 & 8.7 & 0.9 & 11.7 & 3 & Red \\
\hline WX15 & Willhite & 37,175 & 10 & 12.6 & 9.3 & 0.8 & 15.8 & 4 & Red \\
\hline
\end{tabular}


Table 5. An example of a summer squash variety trial in which the fruit color types could have been grouped for ease of comparison.

\begin{tabular}{|c|c|c|c|c|c|c|c|}
\hline \multirow[b]{2}{*}{ Variety } & \multirow{2}{*}{$\begin{array}{l}\text { Seed } \\
\text { source }^{\mathrm{z}}\end{array}$} & \multirow{2}{*}{$\begin{array}{l}\text { Color } \\
\text { type }^{y}\end{array}$} & \multicolumn{5}{|c|}{ Yield (lb/acre) $)^{x}$} \\
\hline & & & Total & Small $^{\mathrm{w}}$ & Medium $^{\mathrm{w}}$ & Large $^{w}$ & Culls \\
\hline Dividend & Syngenta & GZ & 3553 & 1063 & 966 & 1185 & 339 \\
\hline Cashflow & Syngenta & GZ & 2696 & 856 & 872 & 830 & 139 \\
\hline Multipik & Harris-Moran & YS & 2522 & 684 & 885 & 754 & 199 \\
\hline Consul R & Seminis & GZ & 2417 & 586 & 609 & 1007 & 214 \\
\hline
\end{tabular}

${ }^{\mathrm{z}}$ Harris-Moran = Harris-Moran Seed Co., Modesto, Calif.; Seminis = Seminis Vegetable Seeds Inc., Oxnard, Calif.; Syngenta = Syngenta Seeds Inc., Boise, Idaho.

${ }^{\mathrm{y}} \mathrm{GZ}=$ green zucchini, YS = yellow straightneck.

${ }^{\mathrm{x}} 1 \mathrm{lb} /$ acre $=1.12 \mathrm{~kg} \cdot \mathrm{ha}^{-1}$.

${ }^{\mathrm{w}}$ Small $=<6$ inches $(15.2 \mathrm{~cm})$ diameter, medium $=6-8$ inches $(20.3 \mathrm{~cm})$ diameter, large $=>8$ inches diameter.

Table 6. An example of the advantage of grouping summer squash variety performance results by fruit type and disease information.

\begin{tabular}{|c|c|c|c|c|c|c|c|c|c|}
\hline \multirow[b]{2}{*}{ Entry } & \multirow{2}{*}{$\begin{array}{c}\text { Breeding } \\
\text { type }^{z}\end{array}$} & \multirow{2}{*}{$\begin{array}{c}\text { Claimed } \\
\text { resistance }^{\mathrm{y}}\end{array}$} & \multirow{2}{*}{$\begin{array}{c}\text { Marketable } \\
\text { yield } \\
\text { (boxes/acre) }^{\mathrm{x}} \\
\end{array}$} & \multicolumn{2}{|c|}{$\begin{array}{c}\text { Virus } \\
\text { incidence (\%) }\end{array}$} & \multicolumn{2}{|c|}{ ELISA $^{\mathbf{w}}$} & \multirow{2}{*}{$\begin{array}{c}\text { Powdery } \\
\text { mildew }^{2} \\
(\%) \\
\end{array}$} & \multirow{2}{*}{$\begin{array}{c}\text { Downy } \\
\text { mildew } \\
(\%) \\
\end{array}$} \\
\hline & & & & 22 Sept. & 12 Oct. & WMV & CMV & & \\
\hline \multicolumn{10}{|c|}{ Yellow straightneck } \\
\hline Fortune & $\mathrm{C}-\mathrm{Py}$ & & 1710 & 94 & 80 & + & - & 67 & 10 \\
\hline XPHT 1816 & $\operatorname{Tg}-4$ & $\mathrm{Z}, \mathrm{C}, \mathrm{W}, \mathrm{R}$ & 1699 & 0 & 73 & + & - & 10 & 38 \\
\hline Multipik & C-Py & & 1699 & 70 & 94 & + & - & 77 & 21 \\
\hline \multicolumn{10}{|c|}{ Yellow crookneck/semicrookneck } \\
\hline Prelude II & Tg-2 & $\mathrm{Z}, \mathrm{W}, \mathrm{P}$ & 1599 & 0 & 29 & - & - & 5 & 42 \\
\hline Destiny III & $\mathrm{Tg}-3$ & $\mathrm{Z}, \mathrm{C}, \mathrm{W}$ & 1571 & 0 & 79 & - & + & 88 & 80 \\
\hline Sundance & $\mathrm{C}$ & & 1225 & 79 & 100 & + & - & 47 & 47 \\
\hline \multicolumn{10}{|l|}{ Zucchini } \\
\hline Revenue & $\mathrm{C}$ & $\mathrm{Z}, \mathrm{C}, \mathrm{W}$ & 2220 & - & 47 & + & - & 77 & 28 \\
\hline President & $\mathrm{C}$ & & 2170 & - & 37 & + & - & 57 & 30 \\
\hline Dividend & $\mathrm{C}$ & $\mathrm{Z}, \mathrm{C}, \mathrm{W}$ & 2125 & - & 75 & + & - & 95 & 35 \\
\hline
\end{tabular}

${ }^{\mathrm{z}} \mathrm{C}=$ conventional breeding, $\mathrm{Tg}=$ transgenic breeding, $2,3,4=$ resistance to 2,3 , or 4 viruses Py $=$ precocious yellow

$\mathrm{y} \mathrm{Z}=$ zucchini yellows mosaic virus, $\mathrm{C}=$ cucumber mosaic virus, $\mathrm{W}=$ watermelon mosaic virus, $\mathrm{P}=$ papaya ringspot virus.

${ }^{\mathrm{x}} \mathrm{l}$ box $/$ acre $=21 \mathrm{lb} /$ acre $=23.5 \mathrm{~kg} \cdot \mathrm{ha}^{-1}$.

${ }^{w}(+)$ Enzyme-linked immunosorbent assay (ELISA) positive for presence of watermelon mosaic virus (WMV) and cucumber mosaic virus (CMV), (-)ELISA negative for presence of WMV and CMV

${ }^{\mathrm{v} C a u s a l}$ organism $=$ Sphaerotheca fuliginea

"Causal organism $=$ Psendoperonospora cubensis

Table 7. An example of a tomato variety trial in which data could have been improved by supplying information on fruit size.

\begin{tabular}{|c|c|c|c|c|c|c|c|}
\hline \multirow[b]{2}{*}{ Cultivar } & \multirow[b]{2}{*}{ Source ${ }^{\mathrm{z}}$} & \multicolumn{3}{|c|}{ U.S. No. 1} & \multirow{2}{*}{$\begin{array}{c}\text { Total U.S. No.1 } \\
\text { (1b/plant) }^{\mathrm{y}} \\
6 \text { July-31 Aug. }\end{array}$} & \multirow[b]{2}{*}{$\begin{array}{l}\text { Total yield } \\
6 \text { July-31 Aug. }\end{array}$} & \multirow{2}{*}{$\begin{array}{r}\text { Culls } \\
\text { (no./ } \\
\text { plant) } \\
\end{array}$} \\
\hline & & $\begin{array}{c}\text { Early } \\
\text { 6-19 July }\end{array}$ & $\begin{array}{c}\text { Midseason } \\
7 \text { July-9 Aug. }\end{array}$ & $\begin{array}{c}\text { Late } \\
\text { 12-31 Aug. }\end{array}$ & & & \\
\hline NC 98128 & NCSU & 0.6 & 9.8 & 10.5 & 20.9 & 20.9 & 4.4 \\
\hline RFT 6116 & Syngenta & 0 & 4.4 & 6.8 & 11.2 & 16.9 & 9.8 \\
\hline Carolina Gold & NCSU & 0.2 & 5.8 & 5 & 11 & 16.1 & 7.5 \\
\hline Sunbright & Seminis & 0.1 & 7.4 & 2.9 & 10.4 & 14.5 & 7.3 \\
\hline EX 10091 & Seminis & 0.3 & 4.7 & 5.2 & 10.2 & 15.9 & 7.3 \\
\hline
\end{tabular}

${ }^{\mathrm{z} N C S U}=$ North Carolina State University, Mountain Horticultural Crops Research and Extension Center, Fletcher, N.C.; Seminis = Seminis Vegetable Seeds, Inc., Oxnard, Calif.; Syngenta = Syngenta Seeds, Inc., Boise, Idaho.

y $1.0 \mathrm{lb}=0.45 \mathrm{~kg}$.

Charges for entries. Due to funding shortfalls at universities, there are very few free variety trials anymore. This translates into a selection process by each seed company to choose the best cooperators and, in some cases, limit the coverage that they once had when there was no cost to the company. It also presents private industry with the prospect of conducting their own variety trials in growers' fields, thus bypassing university or extension trialing altogether.

Recognition. This may be the single most influential factor in fewer variety trial reports. Until the relatively recent introduction of HortTechnology as a refereed publication for variety re- porting, little publication creditwas available to public-sector horticulturists. Research and extension personnel are facing increased expectations to publish refereed manuscripts, and variety trials traditionally have been deemed unsuitable for major peer-reviewed journals.

Grower apathy. I do not know if this is real or perceived, and perhaps it 
Table 8. An example of data from a tomato variety trial that is useful for determining the economic value of the varieties tested.

\begin{tabular}{|c|c|c|c|c|c|c|c|c|}
\hline \multirow[b]{3}{*}{ Variety } & \multirow[b]{3}{*}{ Source $^{\mathrm{y}}$} & & & \multirow{3}{*}{$\begin{array}{c}\text { Avg wt } \\
\text { (1b) }\end{array}$} & \multicolumn{4}{|c|}{ No. 1 fruit $^{z}$ [\% (by wt)] } \\
\hline & & \multicolumn{2}{|c|}{ Yield/plant } & & \multirow{2}{*}{$\begin{array}{c}\text { Max } \\
\text { Large }\end{array}$} & \multirow{2}{*}{$\begin{array}{c}\text { Extra } \\
\text { Large }^{x}\end{array}$} & \multirow{2}{*}{\multicolumn{2}{|c|}{$\begin{array}{cc} & \text { Medium + } \\
\text { Large }^{\mathrm{x}} & \text { Small }^{\mathrm{x}}\end{array}$}} \\
\hline & & (no.) & wt $(\mathbf{l b})^{\mathrm{x}}$ & & & & & \\
\hline Carolina Gold & Syngenta & 21 & 11.4 & 0.57 & 45 & 44 & 10 & 0.8 \\
\hline Emperador & Seminis & 23 & 12.6 & 0.58 & 48 & 42 & 10 & 0.3 \\
\hline Floralina & Seminis & 36 & 18.4 & 0.53 & 35 & 54 & 10 & 0.9 \\
\hline Florida 47 & Seminis & 28 & 15.4 & 0.57 & 40 & 49 & 10 & 1.1 \\
\hline Florida 91 EX 10091 & Seminis & 25 & 15 & 0.62 & 60 & 35 & 4 & 0.2 \\
\hline
\end{tabular}

${ }^{\mathrm{z}}$ Maximum Large $>3.47$ inches $(8.81 \mathrm{~cm})$ diameter, Extra Large $=3.47-2.875$ inches $(7.30 \mathrm{~cm})$ diameter, Large $=2.875-2.5$ inches $(6.35 \mathrm{~cm})$ diameter,

Medium $=2.5-2.25$ inches $(5.72 \mathrm{~cm})$ diameter, $S$ mall $=2.25-2.125$ inches $(5.40 \mathrm{~cm})$ diameter.

ySeminis $=$ Seminis Vegetable Seeds, Inc., Oxnard, Calif.; Syngenta = Syngenta Seeds, Inc., Boise, Idaho

${ }^{\mathrm{x}} 1.00 \mathrm{lb}=0.454 \mathrm{~kg}$

varies by region, but it seems there is not the grower interest in attending variety trial field days that there used to be- or should be. This could be a reflection of the improved efforts of universities and seed companies to report variety trial results; yet, the most immediate impact that a good variety trial can have is for growers to witness and discuss the performance of varieties with the trial coordinator. So, if it is true that there is less grower enthusiasm for attending public variety trial field days, the public researcher is not going to devote much time to organizing variety trials and collecting data.

HARd wORK. The collection of valid variety trial data is a hard task. Just ask anyone who has had a summer squash (Cucurbita pepo), cucumber (Cucumis sativus), or okra (Abelmoschus esculentus) variety trial! Many vegetable trials have to be harvested frequently and a lot of pertinent data must be recorded. For some horticulturists, this is too time-consuming, but the information from a good variety trial report is vital.

\section{Benefits of good variety trials}

Some of the beneficiaries of good vegetable variety reporting are as follows.

Growers. The grower is our customer and your customer! Dissemination of variety performance through extension or refereed publications is as vital to the grower as any other input.

Suppliers. In most instances, suppliers are seed companies. We consider good variety reports to be essential to our decision-making process. The public evaluator eliminates bias from their trials - an important feature.

Consumers. Ultimately the consumer is the beneficiary of variety per- formance, especially as it pertains to output traits such as better eating quality and nutritional factors.

Horticulturists. Now that Hort Technology offers a format for publication credit, variety trial reporting should be more active and standardized.

\section{Keys to a good variety trial}

What are the most important components of a valid vegetable variety trial?

Appropriate checks. For the interpretation of results to be valid, it is important to have varieties included in the trial that represent the most commonly grown commercial products. How many varieties should be included? This depends on several factors, not the least of which is budget and time. A good rule of thumb is to include newly commercialized varieties and limit experimental entries to only those likely to be sold. In the industry, these are referred to as advanced experimental varieties - those that have demonstrated some positive field performance.

Suitable Replications. Two replications are the minimum, but three or four are generally needed. This, to some extent, is predicated upon space and budget.

TyPICAL PRODUCTION PRACTICES. It is equally important to conduct a variety trial using the most common production practices of the area. Often, variety trials are conducted in grower's fields, which is usually best. However, beware of the anxious grower: I have witnessed many trials that were accidentally harvested.

Adequate stands. This is always a debatable issue, but we in industry would prefer a minimum of 24 to 30 plants per entry, depending on the species, of course. This would be too few for radish (Raphanus satious), for example.

Normal PLANT AND fRUit EXPREssion. Usually you can tell whether a variety trial is going to provide meaningful results before you even get into the field, based on the plant and field condition. If the trial is excessively weedy or the plants are heavily diseased, the results will be negatively affected. Fruit expression in terms of size, shape, and quality needs to be typical; that is one reason for having checks in the trial. Another critical issue is fruit maturity. Has anyone ever tried to evaluate a watermelon trial when the fruit are not fully ripe? It cannot be done. Problems also can occur when varieties with different maturity dates are planted simultaneously and harvested simultaneously, as some varieties may be underripe, while others are overripe.

Collection of pertinent data. This is really the foundation of a good variety trial, regardless of species. This issue will be addressed in much of the balance of this paper, including some reports that have good data and others that could use improvement. It would certainly be valuable for industry to have a standardized variety-assessment protocol across regions for each species. An example of attempting to standardize watermelon variety evaluations is presented in this article. It seems that standardization of variety evaluations would be best discussed and implemented in each of the vegetable commodity groups.

Statistical analysis. At least some form of statistical analysis and mean separation must be imposed on the data to identify the best performers in terms of yield. Ideally, data from different states or regions could be combined, and statistical analyses could 
Total fruit

\begin{tabular}{|c|c|c|c|c|c|c|c|c|}
\hline \multicolumn{3}{|c|}{ Early yield/plant (8-18 Aug.) } & \multicolumn{2}{|c|}{ Yield/plant } & No. 1 & No. 2 & Culls & \multirow{2}{*}{$\begin{array}{c}\text { Catface } \\
{[\% \text { (by no.)] }}\end{array}$} \\
\hline (no.) & wt (lb) & {$[\%$ (by wt)] } & (no.) & wt (1b) & & (by w & & \\
\hline 5 & 3.3 & 34 & 41 & 23 & 48 & 13 & 39 & $1.6 \mathrm{a}-\mathrm{d}$ \\
\hline 6.2 & 4.4 & 39 & 40 & 22 & 55 & 12 & 33 & $1.4 \mathrm{a}-\mathrm{c}$ \\
\hline 8.6 & 5 & 30 & 53 & 27 & 69 & 10 & 21 & $2.5 \mathrm{~b}-\mathrm{d}$ \\
\hline 5.7 & 3.5 & 24 & 45 & 24 & 64 & 12 & 24 & $0.9 \mathrm{ab}$ \\
\hline 3.8 & 2.7 & 19 & 39 & 23 & 64 & 15 & 20 & $2.8 \mathrm{~cd}$ \\
\hline
\end{tabular}

be computed over all individual tests combined.

Timely PUblication Of RESUlts. To those of us in the seed industry, getting trial information is the key to making production and marketing decisions, so the sooner the better! Publishing in HortTechnology may have drawbacks for industry because of the time lag. Sometimes we can get the raw data from a trial cooperator, and that is sufficient information. A maximum turnaround time of 6 months for HortTechnology variety trial manuscripts would be acceptable.

\section{Cultivar uniformity and communication enhancement}

A survey was conducted by Warren Roberts (Oklahoma State University), who is attempting to standardize watermelon variety evaluation across all regions of the U.S. This project was supported, in part, by the National Watermelon Promotion Board. Roberts started with a questionnaire that was distributed to more than 150 people with a response return of $33 \%$. In the survey, respondents were asked to rank the relative importance of all the principle characteristics of watermelon on a 1 (low) to 5 (high) scale. Figures 1 to 5 provide the survey results that are the most important parameters for watermelon variety assessment. Some parameters such as nutritional levels (vitamins and lycopene) were considered important but are not easily evaluated. Figure 6 displays a few comments from the respondents supporting the value of a standardization approach. This year, Roberts and Frank Dainello (Texas Cooperative Extension Service) are collaborating on the implementation of a standard evaluation protocol for watermelon to be used in Texas and Oklahoma, based on Roberts' survey results. For any horticulturist thinking of standardizing variety evaluations for your crop, a survey such as this is one way to do it.

\section{Vegetable variety evaluation demonstrations}

Avaluable reference recommended for use for conducting scholarly vegetable variety trials is "Vegetable Variety Evaluation Demonstrations: A Manual for County Extension Faculty" (Maynard, 1987). This publication is edited by Don Maynard (University of Florida) and published by the Florida Cooperative Extension Service. Again, I want to emphasize the opportunity of publishing variety trial results in HortTechnology and getting publication credit for it. This was a long time in coming!

\section{Some dos and don'ts of variety reporting}

Tables 1 to 8 are examples from several vegetable variety trial reports. The location of these trials was omitted so as to not embarrass the researcher or appear critical of any variety trial results. My point is to draw attention to reports that have good information and others that have deficiencies. This is simply food for thought, but it does indicate the wide disparity in variety performance reporting and suggests strongly that horticulturists in the public and private sector could be best served by agreeing to standardize evaluation procedures.

Table 1 presents variety trial results for watermelon with generally good data points. However, in the footnotes, it is stated that the plant spacing was $15 \mathrm{ft}^{2}\left(1.4 \mathrm{~m}^{2}\right)$ per plant. Since most watermelons are grown in an area of at least 24 to $36 \mathrm{ft}^{2}$ (2.2 to $3.3 \mathrm{~m}^{2}$ ) per plant, the spacing in this trial was too close, resulting in smallerthan-average fruit.

Table 2 summarizes seeded watermelon trials at two locations and includes the germination results. This information is not essential to diploid variety performance, since germination is usually high and a function of environmental conditions, not variety differences.

Table 3 includes some basic data points for watermelon, but it could have been enhanced by assigning fleshcolor ratings to the entries.

Table 4 lists a series of watermelon varieties, but only reports the flesh color as red. It would have been more meaningful if color ratings were presented. When flesh colors are listed, a color chart should be consulted to remove ambiguity of color descriptions.

Table 5 contains the results for a summer-squash variety trial without fruit type groupings as shown in Table 6 . In addition, Table 6 assesses the varieties' reactions to diseases, which is useful. However, it should be cautioned that, when diseases are identified in a variety trial, they should be verified by a plant pathologist.

Table 7 is a tomato (Lycopersicon esculentum) variety performance report and lists the yield of U.S. No. 1 fruit. In Table 8 , the yield of No. 1 fruit is subdivided into four size categories, which is a better indication of the market value of a tomato variety.

\section{Conclusions}

Is vegetable variety evaluation and reporting becoming a lost art? I hope not! Current information on the best vegetable varieties is essential to vegetable growers seeking to maximize returns. Administrators are urged to support vegetable variety testing by their faculty who, in turn, should be awarded publication credit in HortTechnology or other reputable peer-reviewed journals.

\section{Literature cited}

Maynard, D.N. 1987. Vegetable variety evaluation demonstrations: A manual for county extension faculty. Univ. Fla. Coop. Ext. Serv. Circ. 762. 